compact; wings short, concave, rounded. Tail short, rounded, of twelve feathers. A bare space behind the eyes. Tongue triangular, fleshy; œsophagus with an ovate oblique crop on the fore part of the neck; stomach a very large and strong gizzard, broader than long, placed obliquely, with concave grinding surfaces; intestine long and wide; cœca large.

\title{
THE COMMON AMERICAN PARTRIDGE.
}

+ Ortix virginiana, Linn.

Plate CClXXXiX.-Male, Female, and Young.

The common name given to this bird in the Eastern and Middle Districts of our Union is that of Quail, but in the Western and Southern States, the more appropriate appellation of Partridge is bestowed upon it. It is abundantly met with in all parts of the United States, but more especially towards the interior. In the States of Ohio and Kentucky, where they are very abundant, they are to be seen in the markets, both dead and alive, in large quantities.

This species performs occasional migrations from the north-west to the south-east, usually in the beginning of October, and somewhat in the manner of the Wild Turkey. For a few weeks at this season, the north-western shores of the Ohio are covered with flocks of Partridges. They ramble through the woods along the margin of the stream, and generally fly across towards evening. Like the Turkeys, many of the weaker Partridges often fall into the water, while thus attempting to cross, and generally perish; for although they swim surprisingly, they have not muscular power sufficient to keep up a protracted struggle, although, when they have fallen within a few yards of the shore, they easily escape being drowned. As soon as the Partridges have crossed the principal streams in their way, they disperse in flocks over the country, and return to their ordinary mode of life.

The flight of these birds is generally performed at a short distance from the ground. It is rapid, and is continued by numerous quick flaps of the wings for a certain distance, after which the bird sails until about to alight, when again it flaps its wings to break its descent. When chased by dogs, or started by wny other enemy, they fly to the middle branches of trees of 
ordinary size, where they remain until danger is over. They walk with ease on the branches. If they perceive that they are observed, they raise the feathers of their head, emit a low note, and fly off either to some higher branch of the same tree, or to another tree at a distance. When these birds rise on wing of their own accord, the whole flock takes the same course; but when put up (in the sportsman's phrase), they disperse, after alighting call to each other, and soon after unite, each running or flying towards the wellknown cry of the patriarch of the covey. During deep and continued snows, they often remain on the branches of trees for hours at a time.

The usual cry of this species is a clear whistle, composed of three notes; the first and last nearly equal in length, the latter less loud than the first, but more so than the intermediate one. When an enemy is perceived they immediately utter a lisping note, frequently repeated, and run off with their tail spread, their crest erected, and their wings drooping, towards the shelter of some thicket or the top of a fallen tree. At other times, when one of the flock has accidentally strayed to a distance from its companions, it utters two notes louder than any of those mentioned above, the first shorter and lower than the second, when an answer is immediately returned by one of the pack. This species has moreover a love-call, which is louder and clearer than its other notes, and can be heard at a distance of several hundred yards. It consists of three distinct notes, the two last being loudest, and is peculiar to the male bird. A fancied similarity to the words Bob White renders this call familiar to the sportsman and farmer; but these notes are always preceded by another, easily heard at a distance of thirty or forty yards. The three together resemble the words $A h$ Bob White. The first note is a kind of aspiration, and the last is very loud and clear. This whistle is seldom heard after the breeding season, during which an imitation of the peculiar note of the female will make the male fly towards the sportsman, who may then easily shoot it.

In the Middle Districts, the love-call of the male is heard about the middle of April, and in Louisiana much earlier. The male is seen perched on a fence-stake, or on the low branch of a tree, standing nearly in the same position for hours together, and calling Ah Bob White at every interval of a few minutes. Should he hear the note of a female, he sails directly towards the spot whence it proceeded. Several males may be heard from different parts of a field challenging each other, and should they meet on the ground, they fight with great courage and obstinacy, until the conqueror drives off his antagonist to another field.

The female prepares a nest composed of grasses, arranged in a circular form, leaving an entrance not unlike that of a common oven. It is placed at the foot of a tuft of rank grass or some close stalks of corn, and is partly 
sunk in the ground. The eggs are from ten to eighteen, rather sharp at the smaller end, and of a pure white. The male at times assists in hatching them. This species raises only one brood in the year, unless the eggs or the young when yet small have been destroyed. When this happens, the female immediately prepares another nest; and should it also be ravaged, sometimes even a third. The young run about the moment after they make their appearance, and follow their parents until spring, when, having acquired their full beauty, they pair and breed.

The Partridge rests at night on the ground, either amongst the grass or under a bent log. The individuals which compose the flock form a ring, and moving backwards, approach each other until their bodies are nearly in contact. This arrangement enables the whole covey to take wing when suddenly alarmed, each flying off in a direct course, so as not to interfere with the rest.

These birds are easily caught in snares, common dead-falls, traps and pens, like those for the Wild Turkey, but proportionate to the size of the bird. Many are shot, but the principal havoc is effected by means of nets, especially in the Western and Southern States. The method employed is as follows:

A number of persons on horseback, provided with a net, set out in search of Partridges, riding along the fences or briar-thickets, which the birds are known to frequent. One or two of the party whistle in imitation of the second call-note above described, and as Partridges are plentiful, the call is soon answered by a covey, when the sportsmen immediately proceed to ascertain their position and number, seldom considering it worth while to set the net when there are only a few birds. They approach in a careless manner, talking and laughing as if merely passing by. When the birds are discovered, one of the party gallops off in a circuitous manner, gets in advance of the rest by a hundred yards or more, according to the situation of the birds, and their disposition to run, while the rest of the sportsmen move about on their horses, talking to each other, but at the same time watching every motion of the Partridges. The person in advance being provided with the net, dismounts, and at once falls to placing it, so that his companions can easily drive the Partridges into it. No sooner is the machine ready, than the net-bearer remounts and rejoins the party. The sportsmen separate to a short distance, and follow the Partridges, talking and whistling, clapping their hands, or knocking upon the fence-rails. The birds move with great gentleness, following each other, and are kept in the right direction by the sportsmen. The leading bird approaches and enters the mouth of the net, the others follow in succession, when the net-bearer leaps from his horse, runs up and secures the entrance, and soon despatches

VoL. V. 
the birds. In this manner, fifteen or twenty Partridges are caught at one driving, and sometimes many hundreds in the course of a day. Most netters give liberty to a pair out of each flock, that the breed may be continued.

The success of driving depends much on the state of the weather. Drizzly rain or melting snow are the best, for in such weather Partridges and gallinaceous birds in general will run to a great distance rather than fly; whereas if the weather be dry and clear, they generally take to wing the moment they discover an intruder, or squat so that they cannot be driven without very particular care. Again, when the flocks are found in the woods, they run off so briskly and so far, that it is difficult for the net-bearer to place his machine in time.

The net is cylindrical, thirty or forty feet in length, by about two in diameter, excepting at the mouth or entrance, where it is rather larger, and at the extremity, where it assumes the form of a bag. It is kept open by means of small wooden hoops, at a distance of two or three feet from each other. The mouth is furnished with a semi-circular hoop, sharpened at both ends, which are driven into the ground, thus affording an easy entrance to the birds. Two pieces of netting called wings, of the same length as the cylindrical one, are placed one on each side of the mouth, so as to form an obtuse angle with each other, and are supported by sticks thrust into the ground, the wings having the appearance of two low fences leading to a gate. The whole is made of light and strong materials.

The Virginian Partridge is easily kept in cages or coops, and soon becomes very fat. Attempts at rearing them from the eggs have generally failed, probably for want of proper care, and a deficiency of insects, on which the young feed. The ordinary food of the species consists of seeds of various kinds, and such berries as grow near the surface of the ground, along with which they pick up a quantity of sand or gravel. Towards autumn, when the young have nearly attained their full size, their flesh becomes fat, juicy and tender, and being moreover white and extremely agreeable to the palate, is in much request. Twenty years ago, they were commonly sold at twelve cents the dozen. They suffer greatly in the Middle Districts during severe winters, and are killed in immense numbers.

This bird has béen introduced into various parts of Europe, but is not much liked there, being of such pugnacious habits as to drive off the common Grey Partridge, which is considered a better bird for the table.

This species occurs far up the Missouri; and is extremely abundant in Texas, where it principally keeps on the prairies. In the Floridas I found it all over the pine barrens; but none were seen on any of the Keys. In Texas, the Floridas, and as far eastward as the neighbourhood of Charleston, 
in South Carolina, it breeds twice in the year, first in May, and again in September. The following is an account of some attempts to domesticate this bird made by my friend Dr. BaChMan:-

"Several years ago I made an attempt to domesticate the Virginian Partridge, and, contrary to the usually received opinion, I was quite successful. The eggs had been obtained from the fields, and were hatched under a Bantam hen. By confining the young with their foster-mother for a few days, they soon learned to follow her like young chickens. They were fed for a couple of weeks on curds, but soon began to eat cracked Indian corn, and several kinds of millet. They were permitted to stray at large in my garden; but fearing that they might be induced to fly over the enclosure and stray away, I amputated a joint of the wing. There was no difficulty in preserving them during the summer and winter, and they became so very gentle that they were in the habit of following me through the house, and often seated themselves for hours on the table at which I was writing, occasionally playfully picking at my hand, and running off with my pen. At night they nestled in a coop placed for that purpose in the garden. The cats in the neighbourhood, unfortunately for my experiment, took a fancy to my birds, and carried off several, so that at the breeding season my stock was reduced to two females, with a greater number of males. The latter now commenced their not unmusical notes of "bob white," at first low, but increasing in loudness and energy till they were heard through the whole neighbourhood. These notes were precisely similar to those of the wild birds, affording a proof that they were natural and not acquired by an association with those of their own species, as these birds had no opportunity of hearing any other notes than those of the poultry on the premises. As the spring advanced, the males became very pugnacious, and continual contests took place among themselves, as well as with the Pigeons, and the young poultry that occasionally intruded on their domicile. In May they commenced laying, both in one nest, in a box placed for the purpose. The eggs were all impregnated, and on being placed under a hen were hatched. A variety of engagements interrupted my attending to them afterwards, and by some accident I was prevented from pursuing my experiment farther. My friend Dr. WiLson, however, was still more successful than I had been. He placed in his aviary severai birds of this species that had been caught in a trap in an adult state. These, in the following spring, sought out secluded nooks overhung by branches of shrubbery, where they built their nests, and laid their eggs. The males and females both sat upon them by turns, and in some instances all the eggs in the nest were hatched. They were much attached to their young, sheltered them under their wings, and endeavoured to protect them from the persecution of other birds confined in the aviary. 
Owing, however, to the small space in which they were confined, none of the young were finally raised. These experiments, however, as far as they went, convinced us that this species may be easily domesticated, and that if they are preserved from being molested by cats and other enemies, they may be kept in enclosures and multiplied to a considerable extent."

The eggs measure an inch and a quarter in length, seven and a half eighths in breadth, and taper to a small rounded point.

Quall or Partridge, Perdix virginiana, Wils. Amer. Orn., vol. vi. p. 21.

Perdix Virginiana, Bonap. Syn., p. 124.

A merican Partridge or Quail, Nutt. Man., vol. i. p. 647.

Virginian Partridge, Perdix virginiana, Aud. Orn. Biog., vol. i. p. 388; vol. v. p. 564.

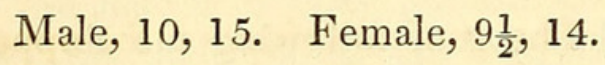

Breeds abundantly from Texas to Massachusetts; in the interior, high on the Missouri, and in all intermediate districts.

Adult Male.

Bill short, robust, rather obtuse, the base covered by feathers; upper mandible with the dorsal outline curved, the sides convex, the edges overlapping, the tip declinate; under mandible nearly straight in its dorsal outline, arched on the edges, the sides convex. Nostrils concealed among the feathers. Head and neck of ordinary size. Body short and bulky. Feet of ordinary length; tarsus anteriorly scutellate, a little compressed, spurless; toes scutellate above, pectinate on the sides; claws arched, obtuse.

Plumage compact, glossy. Feathers of the upper part of the head erectile - into a tuft. Wings short, broad, much curved and rounded, the fourth quill longest. Tail short, rounded, of twelve rounded feathers.

Bill dark brown. Iris hazel. Feet greyish-blue. The forehead, a broad line over each eye, and the throat and fore-neck, white. Lore, auricular coverts, and a broad irregular semilunar band on the fore-neck, more or less black. Upper part of the head, hind and lower part of the neck all round, reddish-brown. Upper back and wing-coverts bright brownish-red; the lower part of the back light red, tinged with yellow. Primaries dusky, externally margined with blue; secondaries irregularly barred with light red. Tail greyish-blue, excepting the middle feathers, which are dull greyish-yellow, sprinkled with black. Sides of the neck spotted with white. Under parts white, streaked with brownish-red, transversely and undulatingly barred with black. Sides and under tail-coverts reddish.

Length 10 inches, extent of wings 15 ; bill along the back $\frac{1}{2}$, along the gap $\frac{7}{12}$; tarsus $\frac{1}{4}$, middle toe nearly the same.

Young Male. 
Similar to the adult male in the general distribution of the colours; but the white of the head and throat bright reddish-yellow, the black of the fore-neck and sides of the head deep brown, the under parts less pure and more dusky, and the tail of a duller grey.

Adult Female.

The female resembles the young male, but is more decidedly coloured, the bill darker, the head of a more uniform and richer reddish-yellow, the sides of the neck spotted with yellow and black.

Length $9 \frac{1}{2}$ inches, extent of wings 14 .

Young Female.

The young females are somewhat smaller and lighter in their tints than the young males.

Very Young Birds.

Bill brownish-yellow. Iris light hazel. The general colour of the upper parts light yellowish-brown, patched with grey; sides of the head dusky.

In a male preserved in spirits, the roof of the mouth is covered posteriorly with large flattened papillæ, and has a very prominent median ridge anteriorly; its width is $5 \frac{1}{2}$ twelfths. The tongue is triangular, fleshy, emarginate and papillate at the base, with one of the papillæ on each side very large. The œsophagus, Fig. 1, $a$ e, which has at first a width of 4 twelfths, forms an ovate oblique crop, $b c, 1$ inch 2 twelfths in its greatest length, and 9 twelfths in breadth, which, together with the œsophagus, lies on the right side of the neck; it then passes obliquely to the left side, forms a proventriculus, $d e$, of an oblong form, 5 twelfths in width, with very large cylindrical glands arranged so as to form a belt $\frac{1}{2}$ inch in breadth. The stomach, $e f g$, is a very large and strong gizzard, broader than long, and placed obliquely, its length 1 inch, its breadth $1 \frac{1}{4}$ inches; the left muscle $3 \frac{1}{2}$ twelfths, the right 5 twelfths thick, the lower muscle very thin, but prominent; the tendons very large; the epithelium very dense and horny, longitudinally rugous; the grinding surfaces concave. The proventricular glands are 3 twelfths in length, the upper inclining downwards, the lower perpendicular. The liver is rather small, the right lobe 1 inch 1 twelfth in length, the left divided into two lobes, of which the anterior is 10 twelfths, the posterior 1 inch in length. The intestine, $g h k$, is of great length and width, the former 26 inches, its average diameter being $2 \frac{3}{4}$ twelfths. The duodenum, $g h i$, curves round the lower edge of the stomach, returns at the distance of $4 \frac{1}{2}$ inches, ascends to the liver, which has two ducts, but is destitute of gall-bladder, then forms seven curves, and terminates in the rectum above the stomach. The cœca, Fig. $2, b c$, come off at the distance of $2 \frac{1}{4}$ inches, and are $4 \frac{1}{4}$ inches in length; their width at the commencement 3 twelfths, their greatest width $4 \frac{1}{2}$ twelfths, their extremity obtuse and con- 
voluted. They are marked with oblique-branched ridges on the inner surface. The intestine at this part is 2 twelfths in width; the rectum, $a b, 2 \frac{1}{2}$ twelfths, without cloacal enlargement.

The trachea is 3 inches 2 twelfths long, flattened; its breadth at the top 2 twelfths, at the lower part 1 twelfth; its rings cartilaginous, about 85; the lower very large, with a membrane intervening between its two portions. The lateral muscles are strong, but there are no inferior laryngeal muscles. The rings of the bronchi are only 10.

Fig. 1.

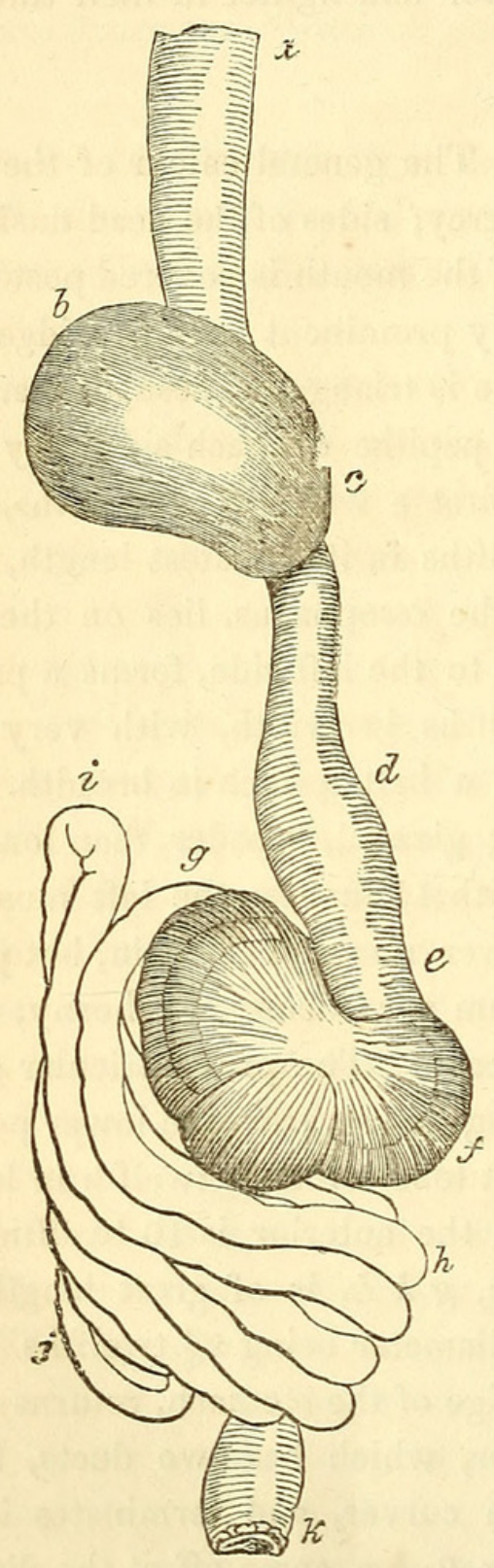

Fig. 2.

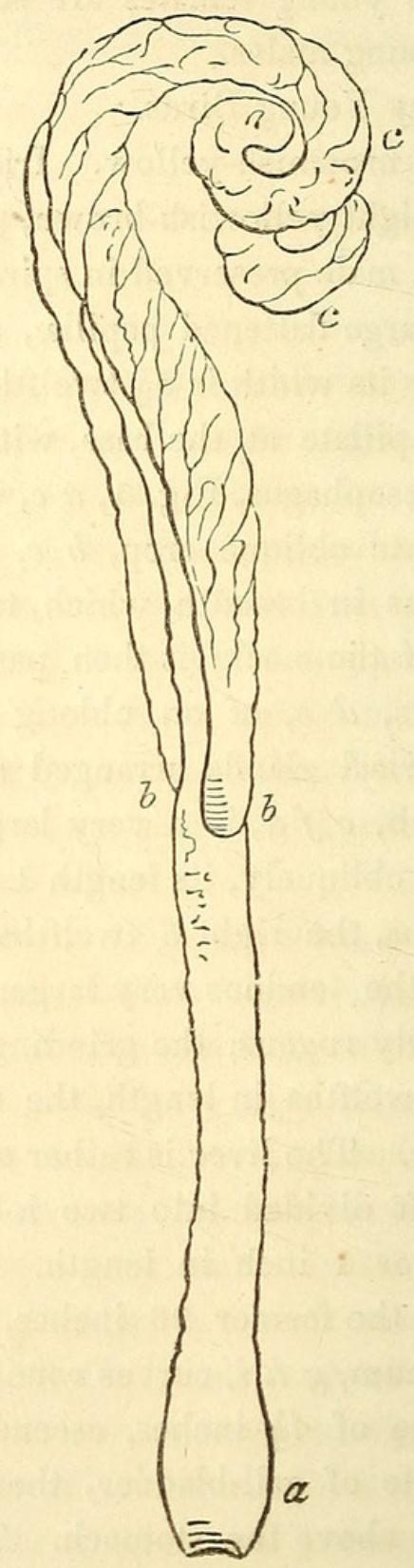


0
$\infty$
0
$\dot{1}$

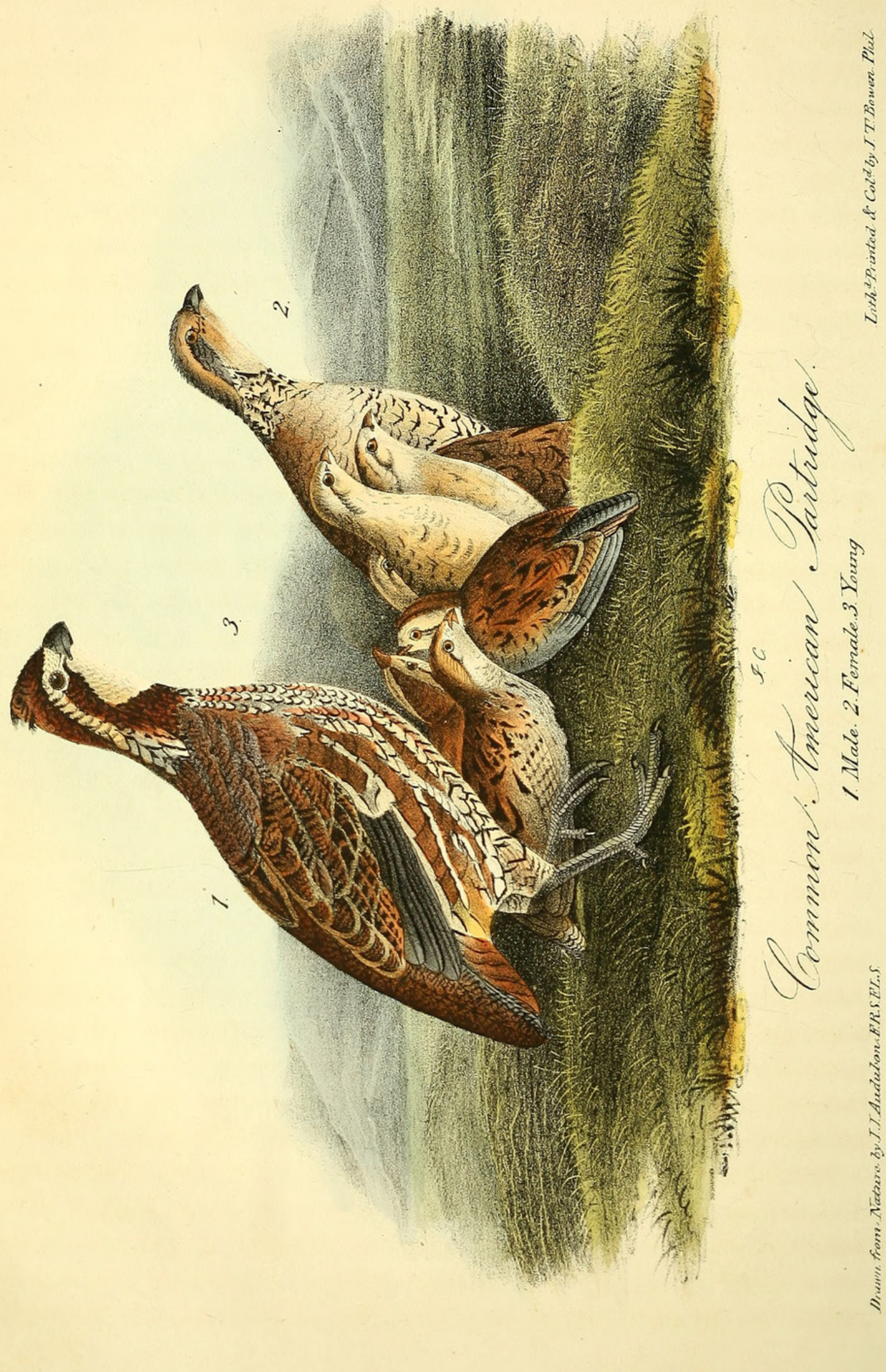




\section{$2 \mathrm{BHL}$ Biodiversity Heritage Library}

Audubon, John James. 1842. "The Common American Partridge, Ortix virginiana, Linn. [PI. 289]." The birds of America : from drawings made in the United States and their territories 5, 59-66. https://doi.org/10.5962/p.319403.

View This Item Online: https://www.biodiversitylibrary.org/item/124982

DOI: https://doi.org/10.5962/p.319403

Permalink: https://www.biodiversitylibrary.org/partpdf/319403

\section{Holding Institution}

Smithsonian Libraries

\section{Sponsored by}

Biodiversity Heritage Library

\section{Copyright \& Reuse}

Copyright Status: NOT_IN_COPYRIGHT

This document was created from content at the Biodiversity Heritage Library, the world's largest open access digital library for biodiversity literature and archives. Visit BHL at https://www.biodiversitylibrary.org. 